\title{
Reconsidering the 1855 Bordeaux Classification of the Medoc and Graves using Wine Ratings from 1970-2005
}

\author{
Gary M. Thompson ${ }^{1 *}$ and Stephen A. Mutkoski ${ }^{2}$ \\ Cornell University
}

\author{
${ }^{1}$ School of Hotel Administration, \\ Cornell University, \\ Ithaca, NY 14853. \\ E-mail: gmtl@cornell.edu \\ *corresponding author \\ ${ }^{2}$ Beverage Management Center, \\ School of Hotel Administration, \\ Cornell University, \\ Ithaca NY 14853. \\ E-mail: sam29@cornell.edu.
}

\section{Acknowledgement}

We thank the editor and referee for suggestions on the earlier versions of the manuscript. Special thanks go to Youngran Bae, Liliana Ielecqua and Se Bum Oh for collecting the data that made this study possible. 


\begin{abstract}
This paper examines ratings of Bordeaux wines from vintages spanning 1970 to 2005. We use ratings from three popular rating sources - Robert Parker (The Wine Advocate), Stephen Tanzer (International Wine Cellar), and Wine Spectator - to examine differences and consistencies in ratings. Our study is based on over 3,100 ratings for chateau/vintage/rater combinations for the "classified growths" as identified in the 1855 Classification. We developed a regression model with rating scores as the depending variable and independent variables for raters, vintages, chateaux and rater-vintage. This model explains $64.6 \%$ of the variation in rating scores. We identify the performance of individual chateaux and use our findings to propose an update to the 1885 classification. Based on the ratings we examined, more than half of the 61 classified growths are misclassified, with some chateaux moving as many as three tiers upward or downward compared to the historical classification. While we believe it is unlikely that the classification will be changed, we believe that our proposed classification update (and our rank-ordering of the chateaux, particularly in relation to price-based orderings) can help guide wine purchase decisions of consumers and the restaurant industry.
\end{abstract}

JEL Classification: L66, C22, Q12, L10 


\section{Reconsidering the 1855 Bordeaux Classification of the Medoc and Graves using Wine Ratings from 1970-2005}

\section{Introduction}

Perhaps the epitome of wine for wine lovers is "Bordeaux" wine, particularly from the Medoc in France. Bordeaux is the largest fine wine producing region in the world and it dominates both the futures market and the auction market for fine wine. This region is known for the quality and longevity of its red wines, which are blended from the grapes of Cabernet Sauvignon, Merlot, Cabernet Franc, Petit Verdot, Malbec and Carmenere. The climate varies significantly from year to year, even among the communes in Bordeaux, but when the ideal conditions materialize in a particular year, like they did in 1982, 2000 and 2005, for example, the wines can be legendary.

In 1855, Bordeaux wines were categorized into five tiers, or "growths," based on the reputation of the wines and their prevailing market prices. In preparation for the 1855 Universal Exposition in Paris, the Bordeaux Chamber of Commerce commissioned the Union of Brokers (Syndicat des Courtiers) in Bordeaux to produce a list of grouped (classified) chateaux ("growths"). These brokers were the middlemen connecting the wine producers to the merchants; they knew the properties and the wines well and they had recorded the selling prices paid for these wines for many years before preparing the official classification. With one minor change, the "1855 Classification" continues in use today, with the 61 chateaux on this list often referred to as the "classified growths." Table 1 presents the current 1885 Classification, including the minor change. Wine prices often follow the classification, with the "first-growth" wines commanding a significant premium over the others. For example, as of early March 2010 prices of the first-growth

wines from the 2005 vintage averaged \$1,153 per standard (0.75 liter) bottle, compared to \$154 for the second-growth wines. Price-based updates to the 1855 classification have been proposed several times in the last 15 years (Ashenfelter, 1997; Di Vittorio and Ginsburgh, 1996) and later in the paper we compare our proposed reclassification to those based on prices.

It is widely accepted today that in any given year there are chateaux that do not produce at the level of their ranking. Some chateaux may continue to underperform for an 
extended period of time. Others manage to out-perform their classification designation and unofficially achieve a new status within their growth designation (i.e., "Super Seconds") and some perform so well they are no longer considered by the marketplace to be in their original category.

Historically, if a consumer wanted to purchase wine, they might do so based on sampling a bottle, perhaps at a restaurant or on the recommendation of friends. Today, however, consumers have other options - wine rating services. Perhaps the best-known rater is Robert Parker and his publication, The Wine Advocate, which was first published in 1978. Two other prominent rating sources are the publication Wine Spectator, which first appeared in 1976, and Stephen Tanzer and his publication, the International Wine Cellar, which was first published in 1985. Details on the rating sources are given in Table 2. In the opinion of many, Robert Parker's influence on wine industry is far more extensive than the circulation of his newsletter would suggest.

All three of these prominent rating services rate wines on a 100-point scale, with a score of 100 given only to "perfect" wines. Table 3 presents the scores and rating descriptions, for each of the rating sources. While the terms the raters use varies, all three appear to agree that wines that rate 90 or higher are outstanding wines. "Americans buy by the numbers - critics' numbers. So, for the next 150 years, scholars can investigate whether, or to what degree, the vertical numerical structure and spirit of the top-down 1855 classification has promoted the top-down 100-point grading system perpetuated by our most famous market-moving claret lover, Robert M. Parker, Jr." (Goldberg, 2005). Later in the paper we investigate the degree of congruence between the raters' ratings of individual wines.

Our goal for this paper is to examine the ratings of Bordeaux wines from 1970 to 2005, using the scores from all three of these rating services. In doing so, we will investigate a number of questions, such as whether there are notable differences between the scores of the raters, between different vintages, and between different chateaux. The structure of the remainder of this paper is as follows. We first address the literature related to ratings. We then describe our data collection and data preprocessing efforts and report on the wide variety of analyses we performed. Finally, we close with some conclusions, including a discussion of the possible extensions to this work. 


\section{Literature Review}

Issues related to ratings have appeared more commonly in the popular press than in the scientific press. A widely held belief is that ratings drive sales. Consider the following quotations. "Above [90], a wine can't be bought; below [90] it can't be sold" (Anonymous, 1999). "Some big retailers wouldn't dream of advertising a wine without its Parker or Wine Spectator rating" (Prial, 1992). ".. .[Consumers irrationally (at least from a wine lover's perspective) chase after bottles that critics have awarded 90 points or more, but shun those in the 85-89 range, even though the lower-rated wines may be cheaper, more flexible with food and readier to drink" (Asimov, 2008).

There is scientific support for the belief that ratings affect sales. In a comprehensive study, Jones and Storchmann (2001) developed an econometric model for Bordeaux wines. They included RP ratings as one of the factors in their model. They found that RP ratings had a significant effect on price, with the prices of Merlotdominated wines being less affected by ratings than the prices of Cabernet Sauvignondominated wines. The RP ratings had a larger effect on the price of wines from the smaller chateaux than on larger chateaux.

Ratings presumably affect sales because consumers wish to buy "better" wines. Prial (1992) stated that "At best, numerical ratings are a fumbling sign language that allows two groups who don't speak the same tongue - the wine trade and wine consumers - to try to communicate". This contention was supported by the research of Hughson and Boakes (2002), who found that wine novices lack the knowledge of varietal types of experts and also lack the vocabulary to describe wines.

Rating scales have received their share of criticism. For example, "...the consumer is fooled into believing that there is something scientific about an activity that is, in fact, quite literally a matter of taste" (Anonymous, 1999). Rivlin (2006) observed that "A rating system that draws a distinction between a cabernet scoring 90 and one receiving an 89 implies a precision of the senses that even many wine critics agree that human beings do not possess." He continues "MANY wine buyers may think that The Number has the same integrity as the ratings that Consumer Reports bestows on products like cars or household appliances. But virtually every critic using the 100-point system deviates from the stringent standards that Consumer Reports, a nonprofit magazine, has adopted to 
ensure objectivity." Ewing-Mulligan and McCarthy (2003) "...think the obsession with [ratings] in wine circles has gotten out of hand - especially when one considers that no real definition exists for wine quality."

A potential source of criticism relates to the proliferation of rating sources, with wine retailers often rating wines as well. Indeed, according to Rivlin (2006) "at least a dozen sources publish a 100-point score." Given that one of the coauthors of this study receives weekly emails from seven wine retailers that use their own rating scales (PJ Wine, Sam's Wines \& Spirits, Shoppers Wines, D. Sokolin \& Company, Ultimate Wine Shop, Wine Library, and Wine Buyer), Rivlin's estimate seems conservative. The proliferation of rating sources, which presumably vary in their assessments of the same wine, offer strong support for Cortese's (2004) advice to wine consumers, "...it's key to find a reviewer you can trust - the same way you trust the opinion of your favorite film critic."

Our purpose in the current study is not to support or refute wine ratings. We simply wish to use the ratings of three prominent sources, while recognizing the inherent limitations of any ratings, to examine whether the historical Bordeaux classification has held up well over time.

\section{Data Collection and Preprocessing}

We collected the data on the ratings of the Bordeaux wines via the websites of each of the raters. Each rating source charges for electronic access to its rating scores. As of March 2010, each was less than $\$ 100$ per year. Our goal was to collect ratings from each rating source for all of the growths from 1970 through 2005. The sources varied in the extent of their ratings. We obtained the greatest number of ratings from RP and the fewest from ST. Overall, we obtained ratings on 1,622 chateau/ vintage combinations, as reported in Table 4, with many wines being rated by two or all three raters. Many of the vintages are well represented in the dataset. For example, we have common ratings from 59 of the 61 classified growth wines from the 2005 vintage. Vintages earlier than 1982 in general are less well represented in the dataset.

Overall, our dataset contains 3,133 chateau/vintage/rater combinations, which indicates that on average, each wine has ratings from approximately half of the three 
raters. In some cases, the same rating source will rate the same wine multiple times. We believe it is important to note that for all of the analyses we performed, we used the highest of the rated scores, since this is, we believe, akin to judging a wine at it peak, and is also the score that is typically communicated to consumers.

\section{Wine Rating Analyses}

In this section we report on a variety of analyses we performed. We look at comparisons across raters, comparisons across vintages, and a number of other analyses.

To explore the consistency across raters, we examined the correlations of the ratings. These results are presented in Table 5. RP and ST have the highest correlation, at 0.862. Even the lowest correlation in ratings, between RP and WS, is, at 0.631 , still a high level of correlation. One possible explanation for the consistency across raters is that the wines themselves have intrinsic characteristics that the raters are capturing in their scores. Further, it would be a necessity that the raters are keying off the same (or related) intrinsic characteristics of the wines.

\section{A. Regression Analysis}

To test the mathematical relationships between the ratings and determinant factors, we developed a regression model, with the rating score as the dependent variable. The independent variables included the raters, the vintages, and the chateaux. We used $\mathrm{RP}$ as the reference rater (simply on the basis of an alphabetical selection), and used binary coding variables to represent the scores of ST and WS. In an initial regression model, we also included linear terms to evaluate whether the ratings of each rater had changed over time. Since these terms were not statistically significant, we removed them from the regression model for which we present the results. We combined the two vintages with the fewest ratings - 1972 and 1977 - to create a reference, and then used binary coding variables to represent the other vintages. With respect to chateaux, we used three fifth-growth chateaux that all were lightly represented in our dataset - Chateau Cantemerle (Macau), Chateau Dauzac Labarde (Margaux), and Chateau Pedesclaux 
(Pauillac) - as the reference ${ }^{1}$ and then used binary coding variables for the other chateaux. The results of our regression analysis are presented in Table 6 and Table 7. Table 6 lists the regression coefficient for the raters and the vintages, while Table 7 lists the regression coefficients for the chateaux. The model explained $64.6 \%$ of the variation in the ratings. In the sections that follow we interpret the results of this regression.

\section{B. Comparing Vintages}

Table 8 presents the regression results with respect to the vintages. We have ordered the vintages by declining rating effect. These results indicate that, based on the 1,622 wines in our dataset, 32 vintages had ratings that were statistically significant, and higher, than the ratings for the reference vintages. The 2005 vintage received the highest scores, with ratings 22.0 points higher than that of the reference years, followed by the 2000 vintage, with ratings that were 21.7 points higher than that of the reference years. The surprise here is that 1982, which many judge as being a stellar year, emerged only as the tenth highest rated vintage. One vintage - 1974 - had ratings that were lower, but statistically indistinguishable from the reference vintages. Another vintage - 1973 scored 4.2 points below the reference vintages, a difference that was statistically significant.

\section{Comparing the Raters}

The regression results provide additional insights into the differences in ratings across rating sources. On average, ST was the most conservative rater while WS was the most generous rater. WS ratings were 1.247 points above those of RP, a statistically significant difference. ST ratings were 0.234 points below those of RP, a difference that was not statistically significant. There are important implications of these differences. It often seems that 90 points is the "magic number" for wine ratings, with wines receiving that rating or higher selling out more quickly than lower-rated wines. Our findings

\footnotetext{
${ }^{1}$ The third growth Chateau Desmirail (Margaux) was also lightly represented in our dataset, but we believed the analysis would be cleaner if we used wines from the same (fifth) growth as the reference.
} 
suggest, however, that 90 points by RP is not the same as 90 points by ST or WS. The difference in the ratings suggests that a 90-point rating from RP or ST is approximately comparable to a 91-point rating from WS. Further, these differences mean that rather than simply choosing wines on the basis of the scores they are awarded, that consumers calibrate their own tastes to those of the raters; in other words, find a rater whose evaluations matches their own tastes. As we noted earlier, while there is a high correlation between the ratings across raters (Table 5), there still are differences. A method we recommend to wine consumers for finding an appropriate rater is as follows. First, select a few wines. Second, give them your own personal ratings, without regard to the ratings available from rating sources. Third, evaluate the quality of the raters to see which of them comes closest to your own ratings. By doing this, then, consumers can leverage the extensive wine tastings made by the rating sources, and then use those ratings to inform their wine purchase decisions.

As we mentioned earlier, we initially included time-dependent, rater-specific terms in the regression model, but the regression coefficients were not statistically significant. One might argue that with improved wine-making skills, wine quality is improving over time. The interesting question with respect to ratings, then, is that whether the standards are static over time or whether the ratings are relative to the general wine practice at the time. The lack of statistical significance suggests the latter.

Table 9 summarizes the average rating scores by rater and growth for the 1,622 wines in our dataset. Ratings of the first growths exceed those of the second, which in turn exceeds those of the third-growth. The ratings of the third- and fourth-growths were similar, and higher than those of the fifth growth. Figure 1 presents much of the data reported in Table 9 in a visual form. This chart shows that both ST and WS give ratings that inversely correspond to the growth (i.e., higher ratings to first growths than second, etc). RP, however, scores the fourth growth wines higher than either of the third- or fifthgrowths.

\section{Across-Rater Consistency}

We examined several aspects of the dataset to get a sense of congruence of the ratings. Figure 2 shows the average rating, by rater, across the vintages. The average 
rating for each vintage is obtained by averaging the scores for all the particular wines in the dataset for that vintage (for each rater) and adjusting for the particular chateaux that were rated. While it may appear that there are more discrepancies in ratings prior to 1990 , it is important to recall that the earlier vintages were underrepresented in our dataset (see Table 4). The apparent reduction in rating variation from 1995 onward may be a result of a general improvement in wine-making expertise over this period.

Figure 3 illustrates the average rating, by chateau, for the three raters. Each data point in Figure 3a represents an average of the ratings from all the vintages for the specific classified growth (for each rater), adjusted by the vintages that were rated. We believe that the degree of consistency in ratings demonstrated by this Figure is quite striking.

\section{E. Reconsidering the 1855 Classification}

The regression results are also useful for ranking the chateaux, in order of declining net rating effects, as reported in Table 10. The "Rating Difference" column represents the rating score differential of the chateaux compared to the reference chateaux (Chateau Cantemerle (Macau), Chateau Dauzac Labarde (Margaux), and Chateau Pedesclaux (Pauillac)). Table 10 also places the chateaux in what we call two "2010 Classifications" based on their rating scores. In the first 2010 Classification (201 OS in Table 10), we assume that each growth in the 2010 Classification will contain the same number of chateaux as did the 1855 Classification. For example, since there are only five 1855 first-growth chateaux, we thus limit the 2010 Classification-S to five first-growths.

Based on the rating performance of the wines in our dataset, a number of chateaux would be rated higher in the 2010 Classification-S than they had been in the 1855 classification. Chateau Leoville-Las-Cases (Saint-Julien) moves to the first growth from the second, Chateau Palmer (Cantenac-Margaux) moves from the third growth to the second, Chateau Saint-Pierre (Saint-Julien) moves from the fourth growth to the second, while four chateaux - Chateau Clerc-Milon (Pauillac), Chateau Grand-Puy-Lacoste (Pauillac), Chateau Lynch-Bages (Pauillac) and Chateau Pontet-Canet (Pauillac) - make large jumps from the fifth growth to the second. Further, Chateau d'Armailhac (Pauillac) jumps to the third growth from the fifth; six chateaux - Chateau Beychevelle (Saint- 
Julien), Chateau Branaire-Ducru (Saint-Julien), Chateau Duhart-Milon-Rothschild (Pauillac), Chateau Lafon-Rochet (Saint-Estephe), Chateau Prieure-Lichine (CantenacMargaux) and Chateau Talbot (Saint-Julien) - move from fourth growth to third growth; and three chateaux - Chateau Batailley (Pauillac), Chateau Grand-Puy-Ducasse (Pauillac) and Chateau Haut-Batailley (Pauillac) - move from the fifth to fourth growth.

Obviously, if some chateaux are moving up, others must be moving down. In total, the 201 OS classification shows two chateaux dropping three growths, seven chateaux dropping two growths, and seven chateaux dropping one growth. Overall, then, the results of the 2010S classification suggest that 33 of the 61 classified growths are performing differently from their original classification. In light of these findings, it is quite apparent that the 1855 classification is notably out of date based on the ratings of these sources, and hence consumers should be wary of using it for their wine purchasing decisions, assuming, again, that their personal preferences map well onto the ratings.

One could argue that with investment in technology, improved vineyard management and wine-making decisions that there would be the potential for more chateaux to reach first or second growth quality and status. Another way to evaluate the applicability of the historical classification is to classify the chateaux into six growths, but let the number of chateaux in each growth be determined based on making the overall classification variance as low as possible. By allowing sixth growths, in essence we are allowing some chateaux - those assigned to the sixth growth - to be dropped from the classification. Table 10, which reports the results of this analysis, as the $2010 \mathrm{~V}$ (for variable numbers in the growths), shows that the number of first growths stays at five chateaux, while the second growth drops to 9 chateaux, the third growth increases to 18 chateaux, the fourth growth increases to 15 chateaux, while the fifth growth drops to 12 chateaux. Most notably, Chateau Marquis d'Alesme-Becker (Margaux) and Chateau Croizet-Bages (Pauillac) would fall off the list of classified growths (i.e., be assigned to a sixth growth). Table 11 summarizes the difference in classification outcomes for the two 2010 classifications, compared to the 1855 classification.

One could also propose that some of the chateaux that did not make it into the 1855 classification produce at a level today which would clearly make them eligible should the classification be revised. While we recognize that a major shakeup of the 1855 
classification is unlikely to occur, in reality the market is already considering these changes. Certainly there is market evidence supporting at least one of the classification changes reported in Table 10. Chateau Leoville-Las-Cases (Saint- Julien), which we place in the revised first growth, sells at over three times the average price of the other 1855 second growths (based on data collected in early May 2008 for the 2005 vintage). Even at this premium, Chateau Leoville-Las-Cases (Saint-Julien) is only about one-third as expensive as the 1855 first-growths. Given that its rating is very close to the 1855 firstgrowths in our dataset, Chateau Leoville-Las-Cases (Saint-Julien) must be viewed as a relative bargain.

Another example supporting these findings comes from a tasting done by Eric Asimov, Frank J. Prial and Florence Fabricant, all from the New York Times, and Jamie Ritchie, the head of Sotheby's North American wine department. In 2005 they tasted blind and ranked 25 classified growths from the 2001 vintage. "We found some correlation between price and quality, but not entirely. After all, our top wine, the PontetCanet from Pauillac, a great value at \$30, was not nearly the highest-priced wine in the tasting. What's more, Pontet-Canet is merely a fifth growth. How could it beat out the three first growths in our tasting, not to mention many of the other, higher-ranking estates?" (Asimov, 2005). Granted this tasting by four people is not a scientific study or a valid sample size, but then neither is a single wine rater's score.

Table 12 reports a comparison of our proposed classification update to three price-based reclassifications. V\&G96 is Di Vittorio and Ginsburgh's (1996) classification update, based on auction prices from 1949 to 1989. A97 is the 1997 reclassification from Ashenfelter (1997), which was based on auction transactions from 1994 to 1996. 05-06SP is a ranking based on spot prices we observed in early March 2010 for the 2005 and 2006 vintages. Comparing the total absolute deviation between the rankings to that of 201 OS (the last row in Table 12), shows an interesting pattern, whereby that the misclassification (total absolute deviation) is greatest for the 1855 classification, but misclassification decreases as the price information moves closer to the present. Nonetheless, there is still a notable discrepancy even between the spot prices observed in early March 2010 and the rating-based classification (2010S). 
The fact that 1,520 wines were rated multiple times by the same rater allows us to analyze the patterns of the ratings over time. Table 13 reports the results of this analysis. Of the 1,520 wines with more than one rating by the same rater, 730 were rated two times. Of the 730 wines, 178 received the same score both times; 278 wines saw a higher score in the later rating; while 274 saw a lower score in the later rating. For wines that were rated more than two times, the likelihood of receiving identical scores decreases. Interestingly, however, the number of wines with scores that increase over time remains quite similar to the wines with scores that decrease over time. Similarly, the number of wines with scores that increase then decrease is quite similar to the number of wines with scores that decrease and then increase. Finally, as the number of ratings increase, there is higher likelihood that the time-based pattern becomes more complex (the "other" pattern).

\section{Conclusions}

\section{A. Key Findings}

We see three key findings from our study. First, is regarding the accuracy of the 1855 Classification. Our results, which would have placed more than half of the chateaux in different categories than the 1855 Classification, offer strong evidence that consumers should not use the historical classification strictly when guiding their purchase decisions (assuming, of course, that the consumers give a high weight to rating scores of wine when making their purchase decisions). For example, our study would have placed some chateaux in as many as three growths higher or lower than was suggested by the 1855 Classification. Indeed, the results go so far as to suggest that two chateaux be dropped from the classification scheme. Interestingly, the ratings-based reclassification does not match the price-based reclassification, suggesting there are values for consumers in the marketplace.

A second key finding was the high levels of correlation we observed between the scores of the three rating services. This suggests that they all are able to identify characteristics of the wines. Finally, there were statistically significant differences between the scores awarded by the raters. WS was the most generous in assigning scores, while ST was the most conservative. ST's scores were about one quarter point lower, on 
average than RP's, while WS's score were about one and a quarter points above RP's. These differences do not mean that one rating source is better than another. Instead, these differences mean that consumers should not consider all identically-rated wines as equivalent, but should consider the source of the ratings when judging the wines. Indeed, the differences suggest that consumers look for a rater whose tastes map well onto their own, and then put more credence on the ratings from that source.

\section{B. Limitations}

There are limitations to most studies, and this is no exception. We see three noteworthy limitations to our study. First, we only examined 3,133 chateau/vintage combinations from a total possible 6,588 chateau/vintage combinations (=61 classified growths times 36 vintages time 3 raters). Thus we have data on over $47 \%$ of the complete population of chateau/vintage/rater combinations. However, our dataset is much more complete for 1995 onwards, where we have 1,521 chateau/ vintage/rater combinations from a possible set of 2,013 (=61 classified growths times 11 vintages times 3 raters).

Second, we based this analysis only on three rating services, all based in the United States of America. One could well argue that the analysis be conducted with raters based in Europe or preferably France. To this criticism, we counter that the rating sources we used are prominent, and that Bordeaux wines are consumed the world over, not just in France.

Third, when a particular wine was rated multiple times by the same rating source, we selected the highest rating for our analyses. The rationale for doing so would be that that score could represent the wine at its peak. We note, though, that the results could well differ had we chosen to use the average rating or the most recent rating for each wine.

\section{Future Studies}

A number of future studies are suggested by our findings. First, it would be interesting to repeat the analysis using the average or most-recent rating of each wine for each rater, to see if the results hold. Second, it would be interesting to repeat the study 
with other rating sources, particularly those based in Europe. Third, it could be insightful to repeat the study for other wine-growing areas, for example California or Australia. 


\section{References}

Anonymous (1999). Playing the rating game. Economist, 352(8137), 94-95.

Ashenfelter, O. (1997). A new objective ranking of the chateaux of Bordeaux. Liquid Assets, 13 (December), 1-6.

Asimov, E. (2005). Wines of the Times; 150 years later, judging the judges of fine Bordeaux. New York Times, June 1. (http://www.nytimes.com/2005/06/01/dining/01wine.html)

Asimov, E. (2008). Three cheers for the also-rans. New York Times, February 13. (http://www.nytimes.com/2008/02/13/dining/13pour.html)

Cortese, A. (2004). Winner by a nose. BusinessWeek, May 3 (http://www.businessweek.com/magazine/content/04_1 8/b3881116_mz070.htm)

Dewey, M. (1998). 1855 A History of the Bordeaux Classification. John Wiley \& Sons: New York.

Di Vittorio, A. and Ginsburgh, V. (1996). Pricing red wines of Medoc vintages from 1949 to 1989 at Christie's Auctions. Journal de la Societe Statistique de Paris, 137, 19-49.

Ewing-Mulligan, M. and McCarthy, E. (2003). What's in a number? Wine is too complex for simple rating system. Nations Restaurant News, 37(40), 24.

Goldberg, H.G. (2005). Dusting off the 1855 Debate. Wine News, Coral Gables FL, April/May, (http://www.thewinenews.com/aprmay05/comment.asp)

Jones, G.V. and Storchmann, K. (2001). Wine market prices and investment under uncertainty: An econometric model for Bordeaux Crus Classes. Agricultural Economics, 26(2), 115-133.

Hughson, A. L. and Boakes, R. A. (2002). The knowing nose: the role of knowledge in wine expertise. Food Quality and Preference, 13(7-8), 463-472.

Prial, F.J. (1992). Wine talk. New York Times, February 12. (http://www.nytimes.com/1992/02/19/garden/wine-talk-971692.html)

Rivlin, G. (2006). Wine ratings might not pass the sobriety test. New York Times, August 13. (http://www.nytimes.com/2006/08/13/business/yourmoney/13rate.htm) 
Table 1. 1855 Bordeaux Classification

\begin{tabular}{|c|c|c|c|}
\hline Growth & Château & Growth & Château \\
\hline 1 & Haut-Brion (Pessac) & 4 & Beychevelle (Saint-Julien) \\
\hline 1 & Lafite-Rothschild (Pauillac) & 4 & Branaire-Ducru (Saint-Julien) \\
\hline 1 & Latour (Pauillac) & 4 & Duhart-Milon-Rothschild (Pauillac) \\
\hline 1 & Margaux (Margaux) & 4 & La Tour-Carnet (Saint-Laurent) \\
\hline \multirow[t]{2}{*}{1} & Mouton-Rothschild (Pauillac) & 4 & Lafon-Rochet (Saint-Estephe) \\
\hline & Elevated in 1973 & 4 & Marquis-de-Terme (Margaux) \\
\hline 2 & Brane-Cantenac (Cantenac-Margaux) & 4 & Pouget (Margaux) \\
\hline 2 & Cos-d'Estournel (Saint-Estephe) & 4 & Prieuré-Lichine (Cantenac-Margaux) \\
\hline 2 & Ducru-Beaucaillou (Saint-Julien) & 4 & Saint-Pierre (St.-Julien) \\
\hline 2 & Durfort-Vivens (Margaux) & 4 & Talbot (Saint-Julien) \\
\hline 2 & Gruaud-Larose (Saint-Julien) & 5 & Batailley (Pauillac) \\
\hline 2 & Lascombes (Margaux) & 5 & Belgrave (Haut-Médoc) \\
\hline 2 & Léoville-Barton (Saint-Julien) & 5 & Camensac (Saint-Laurent) \\
\hline 2 & Léoville-Las-Cases (Saint-Julien) & 5 & Cantemerle (Haut-Médoc) \\
\hline 2 & Léoville-Poyferre (Saint-Julien) & 5 & Clerc-Milon (Pauillac) \\
\hline 2 & Montrose (Saint-Estephe) & 5 & Cos-Labory (Saint-Estephe) \\
\hline 2 & Pichon-Longueville Baron (Pauillac) & 5 & Croizet Bages (Pauillac) \\
\hline \multirow[t]{2}{*}{2} & Pichon Longueville Comtesse de & 5 & Dauzac (Margaux) \\
\hline & Lalande (Pauillac) & 5 & d'Armailhac (Mouton d'Armailhac) \\
\hline 2 & Rauzan-Gassies (Margaux) & & (Pauillac) \\
\hline 2 & Rauzan-Segla (Margaux) & 5 & Grand-Puy-Ducasse (Pauillac) \\
\hline 3 & Boyd-Cantenac (Cantenac-Margaux) & 5 & Grand-Puy-Lacoste (Pauillac) \\
\hline 3 & Calon-Ségur (Saint-Estephe) & 5 & Haut-Bages-Liberal (Pauillac) \\
\hline 3 & Cantenac-Brown (Cantenac-Margaux) & 5 & Haut-Batailley (Pauillac) \\
\hline 3 & Desmirail (Margaux) & 5 & Lynch-Bages (Pauillac) \\
\hline 3 & d'Issan (Margaux) & 5 & Lynch-Moussas (Pauillac) \\
\hline 3 & Ferrière (Margaux) & 5 & Pédesclaux (Pauillac) \\
\hline 3 & Giscours (Labarde-Margaux) & 5 & Pontet-Canet (Pauillac) \\
\hline 3 & Kirwan (Cantenac-Margaux) & 5 & du Tertre (Margaux) \\
\hline 3 & La Lagune (Ludon) & & \\
\hline 3 & Lagrange (Saint-Julien) & & \\
\hline 3 & Langoa-Barton (Saint-Julien) & & \\
\hline 3 & Malescot St. Exupéry (Margaux) & & \\
\hline 3 & Marquis d'Alesme Becker, Margaux & & \\
\hline 3 & Palmer (Cantenac-Margaux) & & \\
\hline
\end{tabular}


Table 2. Details on the Prominent Wine Rating Services

\begin{tabular}{llll}
\hline Rating Source & $\begin{array}{c}\text { Robert Parker } \\
\text { (The Wine Advocate) }\end{array}$ & $\begin{array}{c}\text { Stephen Tanzer } \\
\text { (International Wine Cellar) }\end{array}$ & Wine Spectator \\
\hline $\begin{array}{l}\text { Abbreviation } \\
\text { Website }\end{array}$ & $\begin{array}{l}\text { RP } \\
\text { erobertparker.com }\end{array}$ & $\begin{array}{l}\text { ST } \\
\text { www.wineaccess.com/ } \\
\text { expert/tanzer/newhome. } \\
\text { html }\end{array}$ & $\begin{array}{l}\text { WS } \\
\text { Winespectator.com }\end{array}$ \\
$\begin{array}{l}\text { Circulation } \\
\text { (magazine or }\end{array}$ & $40,000^{*}$ & N & $363,000^{* * *}$ \\
$\begin{array}{l}\text { newsletter) } \\
\text { First published }\end{array}$ & 1978 & 1985 & 1976 \\
\hline
\end{tabular}

*Web search; **Unknown; ***Obtained from publisher's website. 
Table 3. Raters' Description of Wine Quality as Related to Rating Score

\begin{tabular}{|c|c|c|}
\hline Rater & Score & Description \\
\hline \multirow[t]{6}{*}{ RP } & $96-100$ & $\begin{array}{l}\text { An extraordinary wine of profound and complex character displaying all the } \\
\text { attributes expected of a classic wine of its variety. Wines of this caliber are } \\
\text { worth a special effort to find, purchase, and consume. }\end{array}$ \\
\hline & $90-95$ & $\begin{array}{l}\text { An outstanding wine of exceptional complexity and character. In short, these } \\
\text { are terrific wines }\end{array}$ \\
\hline & $80-89$ & $\begin{array}{l}\text { A barely above average to very good wine displaying various degrees of } \\
\text { finesse and flavor as well as character with no noticeable flaws. }\end{array}$ \\
\hline & $70-79$ & $\begin{array}{l}\text { An average wine with little distinction except that it is a soundly made. } \\
\text { In essence, a straightforward, innocuous wine. }\end{array}$ \\
\hline & $60-69$ & $\begin{array}{l}\text { A below average wine containing noticeable deficiencies, such as excessive } \\
\text { acidity and/or tannin, an absence of flavor, or possibly dirty aromas or flavors. }\end{array}$ \\
\hline & $50-59$ & A wine deemed to be unacceptable. \\
\hline \multirow[t]{7}{*}{ ST } & $95-100$ & Extraordinary \\
\hline & $90-94$ & Outstanding \\
\hline & $85-89$ & Very good to excellent \\
\hline & $80-84$ & Good \\
\hline & $75-79$ & Average \\
\hline & $70-74$ & Below average \\
\hline & $<70$ & Avoid \\
\hline \multirow[t]{6}{*}{ WS } & $95-100$ & Classic: a great wine \\
\hline & $90-94$ & Outstanding: a wine of superior character and style \\
\hline & $85-89$ & Very good: a wine with special qualities \\
\hline & $80-84$ & Good: a solid, well-made wine \\
\hline & $75-79$ & Mediocre: a drinkable wine that may have minor flaws \\
\hline & $50-74$ & Not recommended \\
\hline
\end{tabular}

Information drawn from each rating source's website. 
Table 4. Number of Scored Wines by Vintage

\begin{tabular}{lccccccc}
\hline Vintage & \#Wines & Vintage & \#Wines & Vintage & \#Wines & Vintage & \#Wines \\
\hline 1970 & 44 & 1979 & 43 & 1988 & 54 & 1997 & 54 \\
1971 & 35 & 1980 & 24 & 1989 & 56 & 1998 & 55 \\
1972 & 5 & 1981 & 39 & 1990 & 52 & 1999 & 55 \\
1973 & 15 & 1982 & 56 & 1991 & 48 & 2000 & 59 \\
1974 & 17 & 1983 & 48 & 1992 & 45 & 2001 & 58 \\
1975 & 42 & 1984 & 41 & 1993 & 51 & 2002 & 58 \\
1976 & 36 & 1985 & 50 & 1994 & 53 & 2003 & 58 \\
1977 & 14 & 1986 & 57 & 1995 & 55 & 2004 & 57 \\
1978 & 41 & 1987 & 33 & 1996 & 55 & 2005 & 59 \\
& & & & & & Total & 1,622 \\
\hline
\end{tabular}


Table 5. Ratings Correlations Across Raters

\begin{tabular}{lccc}
\hline & $R P$ & $S T$ & $W S$ \\
\hline RP & & 0.862 & 0.631 \\
ST & & 0.706 \\
WS & & \\
\hline
\end{tabular}


Table 6. Regression Results for Score as a Function of Rater and Vintage

\begin{tabular}{lccccc}
\hline Variable & Coeff & Variable & Coeff & Variable & Coeff \\
\hline Intercept & $65.721^{* * *}$ & 1982 & $19.196^{* * *}$ & 1994 & $16.847^{* * *}$ \\
ST & -0.234 & 1983 & $16.441^{* * *}$ & 1995 & $19.909^{* * *}$ \\
WS & $1.247^{* * *}$ & 1984 & $9.187^{* * *}$ & 1996 & $19.544^{* * * *}$ \\
1970 & $14.928^{* * *}$ & 1985 & $18.046^{* * *}$ & 1997 & $16.292^{* * * *}$ \\
1971 & $5.759^{* * *}$ & 1986 & $18.245^{* * *}$ & 1998 & $17.682^{* * *}$ \\
1973 & $-4.208^{* * *}$ & 1987 & $10.717^{* * *}$ & 1999 & $18.129^{* * * *}$ \\
1974 & -1.252 & 1988 & $16.403^{* * *}$ & 2000 & $21.732^{* * *}$ \\
1975 & $13.156^{* * *}$ & 1989 & $19.752^{* * *}$ & 2001 & $19.452^{* * *}$ \\
1976 & $8.276^{* * *}$ & 1990 & $20.25^{* * *}$ & 2002 & $18.953^{* * * *}$ \\
1978 & $13.12^{* * *}$ & 1991 & $12.289^{* * *}$ & 2003 & $21.262^{* * *}$ \\
1979 & $13.029^{* * *}$ & 1992 & $12.823^{* * *}$ & 2004 & $19.693^{* * *}$ \\
1980 & $5.449^{* * *}$ & 1993 & $14.873^{* * *}$ & 2005 & $22.022^{* * * *}$ \\
1981 & $13.803^{* * *}$ & & & & \\
\hline
\end{tabular}

$*$ Significant at alpha $=0.05 ; * *$ significant at alpha $=0.01$ level; $* * *$ significant at alpha $=0.001$ level. 
Table 7. Regression Results for Score as a Function of Château

\begin{tabular}{|c|c|c|c|}
\hline Château Variable & Coeff & Château Variable & Coeff \\
\hline Batailley (Pauillac) & 2.094 & La Lagune (Ludon) & $3.957^{* * *}$ \\
\hline Belgrave (Saint-Laurent) & 0.044 & La Tour-Carnet (Saint-Laurent) & -0.02 \\
\hline Beychevelle (Saint-Julien) & $3.779^{* * *}$ & Lafite-Rothschild (Pauillac) & $10.454^{* * *}$ \\
\hline Boyd-Cantenac (Cantenac- & 1.539 & Lafon-Rochet (Saint-Estephe) & $3.835^{* * *}$ \\
\hline Margaux) & & Lagrange (Saint-Julien) & $4.42 * * *$ \\
\hline Branaire-Ducru (Saint-Julien) & $4.673^{* * *}$ & Langoa-Barton (Saint-Julien) & $4.081^{* * *}$ \\
\hline Brane-Cantenac (Cantenac- & 1.824 & Lascombes (Margaux) & 2.004 \\
\hline Margaux) & & Latour (Pauillac) & $10.794 * * *$ \\
\hline Calon-Segur (Saint-Estephe) & $3.943^{* * *}$ & Léoville-Barton (Saint-Julien) & $6.775^{* * *}$ \\
\hline Camensac (Saint-Laurent) & 0.359 & Léoville-Las-Cases (Saint-Julien) & $9.293 * * *$ \\
\hline Cantenac-Brown (Cantenac- & 2.147 & Léoville-Poyferre (Saint-Julien) & $4.598^{* * *}$ \\
\hline Margaux) & & Lynch-Bages (Pauillac) & $6.187^{* * *}$ \\
\hline Clerc-Milon (Pauillac) & $4.781 * * *$ & Lynch-Moussas (Pauillac) & -0.54 \\
\hline Cos-d'Estournel (Saint-Estephe) & $7.914^{* * *}$ & Malescot-Saint-Exupery & $4.151^{* * *}$ \\
\hline Cos-Labory (Saint-Estephe) & -0.029 & (Margaux) & \\
\hline Croizet-Bages (Pauillac) & $-3.895^{* *}$ & Margaux (Margaux) & $9.177^{* * *}$ \\
\hline d'Armailhac (Pauillac) & $3.337^{* *}$ & Marquis d'Alesme-Becker & -1.523 \\
\hline Desmirail (Margaux) & 0.252 & (Margaux) & \\
\hline d'Issan (Cantenac-Margaux) & 1.537 & Marquis-de-Terme & \\
\hline du Tertre Arsac (Margaux) & 1.152 & (Margaux) & 0.996 \\
\hline Ducru-Beaucaillou (Saint-Julien) & $7.488^{* * * *}$ & Montrose (Saint-Estephe) & $6.593^{* * *}$ \\
\hline $\begin{array}{l}\text { Duhart-Milon-Rothschild } \\
\text { (Pauillac) }\end{array}$ & $3.693^{* * *}$ & $\begin{array}{l}\text { Mouton-Rothschild } \\
\text { (Pauillac) }\end{array}$ & $8.233^{* * *}$ \\
\hline Durfort-Viviens (Margaux) & 1.328 & Palmer (Cantenac-Margaux) & $6.814^{* * *}$ \\
\hline Ferriere (Margaux) & 2.521 & Pichon-Lalande (Pauillac) & $7.955^{* * *}$ \\
\hline Giscours (Labarde-Margaux) & $3.937^{* * *}$ & Pichon-Longueville Baron & $5.168 * * *$ \\
\hline Grand-Puy-Ducasse (Pauillac) & 2.204 & (Pauillac) & \\
\hline Grand-Puy-Lacoste (Pauillac) & $4.719^{* * *}$ & Pontet-Canet (Pauillac) & $4.722 * * *$ \\
\hline Gruaud-Larose (Saint-Julien) & $6.291^{* * * *}$ & Pouget (Cantenac-Margaux) & 1.829 \\
\hline Haut-Bages-Liberal (Pauillac) & 1.019 & Prieuré-Lichine (Cantenac- & $2.984^{* *}$ \\
\hline Haut-Batailley (Pauillac) & $2.446^{*}$ & Margaux) & \\
\hline Haut-Brion (Pessac) & $9.963^{* * *}$ & Rauzan-Gassies (Margaux) & -0.692 \\
\hline \multirow[t]{3}{*}{ Kirwan (Cantenac-Margaux) } & $2.84^{*}$ & Rauzan-Segla (Margaux) & $2.588^{*}$ \\
\hline & & Saint-Pierre (Saint-Julien) & $4.942^{* * *}$ \\
\hline & & Talbot (Saint-Julien) & $4.16^{* * *}$ \\
\hline
\end{tabular}

*Significant at alpha $=0.05 ; * *$ significant at alpha $=0.01$ level; $* * *$ significant at alpha $=0.001$ level. 
Table 8. Scores Differences Across Vintages

\begin{tabular}{lccc}
\hline Vintage & Mean Score Difference & Vintage & Mean Score Difference \\
\hline 2005 & $22.022^{* * *}$ & 1988 & $16.403^{* * *}$ \\
2000 & $21.732^{* * *}$ & 1997 & $16.292^{* * *}$ \\
2003 & $21.262^{* * *}$ & 1970 & $14.928^{* * *}$ \\
1990 & $20.25^{* * *}$ & 1993 & $14.873^{* * *}$ \\
1995 & $19.909^{* * *}$ & 1981 & $13.803^{* * *}$ \\
1989 & $19.752^{* * *}$ & 1975 & $13.156^{* * *}$ \\
2004 & $19.693^{* * *}$ & 1978 & $13.12^{* * *}$ \\
1996 & $19.544^{* * *}$ & 1979 & $13.029^{* * *}$ \\
2001 & $19.452^{* * *}$ & 1992 & $12.823^{* * *}$ \\
1982 & $19.196^{* * *}$ & 1991 & $12.289^{* * *}$ \\
2002 & $18.953^{* * *}$ & 1987 & $10.717^{* * *}$ \\
1986 & $18.245^{* * *}$ & 1984 & $9.187^{* * *}$ \\
1999 & $18.129^{* * *}$ & 1976 & $8.276^{* * *}$ \\
1985 & $18.046^{* * *}$ & 1971 & $5.759^{* * *}$ \\
1998 & 1980 & $5.449^{* * *}$ \\
1994 & $17.682^{* * *}$ & 1974 & -1.252 \\
1983 & $16.847^{* * *}$ & 1973 & $-4.208^{* * *}$ \\
\hline
\end{tabular}

$*$ Significant at alpha $=0.05 ; * *$ significant at alpha $=0.01$ level; $* * *$ significant at alpha $=0.001$ level. 
Table 9. Average Ratings by Rater and Growth

\begin{tabular}{lcccc}
\hline Growth & $R P$ & $S T$ & $W S$ & Average \\
\hline 1 & 89.24 & 88.54 & 91.34 & 89.70 \\
2 & 84.45 & 84.46 & 86.11 & 85.01 \\
3 & 82.48 & 83.09 & 83.91 & 83.16 \\
4 & 83.20 & 82.36 & 83.29 & 82.95 \\
5 & 81.38 & 82.08 & 82.38 & 81.95 \\
Average & 84.15 & 84.11 & 85.41 & 84.55 \\
\hline
\end{tabular}


Table 10. 2010 Reclassification Based on Rating Performance

\begin{tabular}{|c|c|c|c|c|c|c|}
\hline $2010 S$ & $2010 \mathrm{~V}$ & 1855 & Cng-S & Cng-V & Château & Rtg Diff \\
\hline 1 & 1 & 1 & & & Latour (Pauillac) & $10.794^{* * \bullet}$ \\
\hline 1 & 1 & 1 & & & Lafite-Rothschild (Pauillac) & $10.454^{* * *}$ \\
\hline 1 & 1 & 1 & & & Haut-Brion (Pessac) & $9.963^{* * *}$ \\
\hline 1 & 1 & 2 & +1 & +1 & Léoville-Las-Cases (Saint-Julien) & $9.293^{* * *}$ \\
\hline 1 & 1 & 1 & & & Margaux (Margaux) & $9.177^{* * *}$ \\
\hline 2 & 2 & 1 & -1 & -1 & Mouton-Rothschild (Pauillac) & $8.233^{* * *}$ \\
\hline 2 & 2 & 2 & & & Pichon-Lalande (Pauillac) & $7.955^{* * *}$ \\
\hline 2 & 2 & 2 & & & Cos-d'Estournel (Saint-Estephe) & $7.914^{* * * *}$ \\
\hline 2 & 2 & 2 & & & Ducru-Beaucaillou (Saint-Julien) & $7.488 * * *$ \\
\hline 2 & 2 & 3 & +1 & +1 & Palmer (Cantenac-Margaux) & $6.814^{* * *}$ \\
\hline 2 & 2 & 2 & & & Loville-Barton (Saint-Julien) & $6.775^{\star \bullet \bullet}$ \\
\hline 2 & 2 & 2 & & & Montrose (Saint-Estephe) & $6.593^{* * *}$ \\
\hline 2 & 2 & 2 & & & Gruaud-Larose (Saint-Julien) & $6.291^{* \cdots *}$ \\
\hline 2 & 2 & 5 & +3 & +3 & Lynch-Bages (Pauillac) & $6.187^{* * *}$ \\
\hline 2 & 3 & 2 & & -1 & Pichon-Longueville Baron (Pauillac) & $5.168 * * *$ \\
\hline 2 & 3 & 4 & +2 & +1 & Saint-Pierre (Saint-Julien) & $4.942 * *$ \\
\hline 2 & 3 & 5 & +3 & +2 & Clerc-Milon (Pauillac) & $4.781 * * *$ \\
\hline 2 & 3 & 5 & +3 & +2 & Pontet-Canet (Pauillac) & $4.722 * * \bullet$ \\
\hline 2 & 3 & 5 & +3 & +2 & Grand-Puy-Lacoste (Pauillac) & $4.719 * * *$ \\
\hline 3 & 3 & 4 & +1 & +1 & Branaire-Ducru (Saint-Julien) & $4.673 * * *$ \\
\hline 3 & 3 & 2 & -1 & -1 & Léoville-Poyferre (Saint-Julien) & $4.598 * * *$ \\
\hline 3 & 3 & 3 & & & Lagrange (Saint-Julien) & $4.42 \bullet \bullet \bullet$ \\
\hline 3 & 3 & 4 & +1 & +1 & Talbot (Saint-Julien) & $4.16^{* * *}$ \\
\hline 3 & 3 & 3 & & & Malescot-Saint-Exupery (Margaux) & $4.151^{\bullet \bullet \bullet}$ \\
\hline 3 & 3 & 3 & & & Langoa-Barton (Saint-Julien) & $4.081 * * *$ \\
\hline 3 & 3 & 3 & & & La Lagune (Ludon) & $3.957^{* * *}$ \\
\hline 3 & 3 & 3 & & & Calon-Segur (Saint-Estephe) & $3.943^{\star \bullet \bullet}$ \\
\hline 3 & 3 & 3 & & & Giscours (Labarde-Margaux) & $3.937^{* * *}$ \\
\hline 3 & 3 & 4 & +1 & +1 & Lafon-Rochet (Saint-Estephe) & $3.835^{* * *}$ \\
\hline 3 & 3 & 4 & +1 & +1 & Beychevelle (Saint-Julien) & $3.779 * * *$ \\
\hline 3 & 3 & 4 & +1 & +1 & Duhart-Milon-Rothschild (Pauillac) & $3.693^{* * *}$ \\
\hline 3 & 3 & 5 & +2 & +2 & d'Armailhac (Pauillac) & $3.337^{* *}$ \\
\hline 3 & 4 & 4 & +1 & & Prieuré-Lichine (Cantenac-Margaux) & $2.984^{* *}$ \\
\hline 4 & 4 & 3 & -1 & -1 & Kirwan (Cantenac-Margaux) & $2.84^{*}$ \\
\hline 4 & 4 & 2 & -2 & -2 & Rauzan-Segla (Margaux) & $2.588^{\star}$ \\
\hline 4 & 4 & 3 & -1 & -1 & Ferriere (Margaux) & 2.521 \\
\hline 4 & 4 & 5 & +1 & +1 & Haut-Batailley (Pauillac) & $2.446^{*}$ \\
\hline 4 & 4 & 5 & +1 & +1 & Grand-Puy-Ducasse (Pauillac) & 2.204 \\
\hline 4 & 4 & 3 & -1 & -1 & $\begin{array}{l}\text { Cantenac-Brown (Cantenac- } \\
\text { Margaux) }\end{array}$ & 2.147 \\
\hline 4 & 4 & 5 & +1 & +1 & Batailley (Pauillac) & 2.094 \\
\hline 4 & 4 & 2 & -2 & -2 & Lascombes (Margaux) & 2.004 \\
\hline 4 & 4 & 4 & & & Pouget (Cantenac-Margaux) & 1.829 \\
\hline 4 & 4 & 2 & -2 & -2 & Brane-Cantenac (Cantenac-Margaux) & 1.824 \\
\hline 5 & 4 & 3 & -2 & -1 & Boyd-Cantenac (Cantenac-Margaux) & 1.539 \\
\hline 5 & 4 & 3 & -2 & -1 & d'Issan (Cantenac-Margaux) & 1.537 \\
\hline 5 & 4 & 2 & -3 & -2 & Durfort-Viviens (Margaux) & 1.328 \\
\hline 5 & 4 & 5 & & +1 & du Tertre, Arsac (Margaux) & 1.152 \\
\hline
\end{tabular}




\begin{tabular}{lllllll}
5 & 5 & 5 & & & Haut-Bages-Liberal (Pauillac) & 1.019 \\
5 & 5 & 4 & -1 & -1 & Marquis-de-Terme (Margaux) & 0.996 \\
5 & 5 & 5 & & & Camensac (Saint-Laurent) & 0.359 \\
5 & 5 & 3 & -2 & -2 & Desmirail (Margaux) & 0.252 \\
5 & 5 & 5 & & & Belgrave (Saint-Laurent) & 0.044 \\
5 & 5 & 5 & & & Cantemerle (Macau) & 0.000 \\
5 & 5 & 5 & & & Dauzac, Labarde (Margaux) & 0.000 \\
5 & 5 & 5 & & & Pédesclaux (Pauillac) & 0.000 \\
5 & 5 & 4 & -1 & -1 & La Tour-Carnet (Saint-Laurent) & -0.02 \\
5 & 5 & 5 & & & Cos-Labory (Saint-Estephe) & -0.029 \\
5 & 5 & 5 & & & Lynch-Moussas (Pauillac) & -0.54 \\
5 & 5 & 2 & -3 & -3 & Rauzan-Gassies (Margaux) & -0.692 \\
5 & N/A & 3 & -2 & N/A & Marquis d'Alesme-Becker (Margaux) & -1.523 \\
5 & N/A & 5 & & N/A & Croizet-Bages (Pauillac) & $-3.895^{* *}$ \\
\hline
\end{tabular}

$*$ Significant at alpha $=0.05 ; * *$ significant at alpha $=0.01$ level; ***significant at alpha $=0.001$ level. 
Table 11. Summary of the 1855 Classification and 2010 Reclassifications

\begin{tabular}{lccc}
\hline & \multicolumn{2}{c}{ Classification } \\
\cline { 2 - 4 } Number of Châteaux & 1855 & $2010 S$ & $2010 \mathrm{~V}$ \\
\hline First growth & 5 & 5 & 5 \\
Second growth & 14 & 14 & 9 \\
Third growth & 14 & 14 & 18 \\
Fourth growth & 10 & 10 & 15 \\
Fifth growth & 18 & 18 & 12 \\
Moving +3 growths & N/A & 4 & 1 \\
Moving +2 growths & N/A & 2 & 4 \\
Moving +1 growths & N/A & 11 & 12 \\
With no change & N/A & 28 & 26 \\
Moving -1 growths & N/A & 7 & 10 \\
Moving -2 growths & N/A & 2 & 5 \\
Moving -3 growths & N/A & N/A & 1 \\
Removed & N/A & & 2 \\
\hline
\end{tabular}


Table 12. 2010 Reclassification Compared to 1855 and Price-Based Classifications

\begin{tabular}{|c|c|c|c|c|c|}
\hline Château & $2010 S$ & 1855 & $V \& G 96$ & $A 97$ & $05-06 S P$ \\
\hline Batailley (Pauillac) & 4 & 5 & 4 & 4 & 5 \\
\hline Belgrave (Saint-Laurent) & 5 & 5 & 5 & 5 & 5 \\
\hline Beychevelle (Saint-Julien) & 3 & 4 & 2 & 2 & 4 \\
\hline Boyd-Cantenac (Cantenac-Margaux) & 5 & 3 & 4 & 5 & 4 \\
\hline Branaire-Ducru (Saint-Julien) & 3 & 4 & 3 & 3 & 3 \\
\hline Brane-Cantenac (Cantenac-Margaux) & 4 & 2 & 3 & 4 & 3 \\
\hline Calon-Segur (Saint-Estephe) & 3 & 3 & 2 & 3 & 3 \\
\hline Camensac (Saint-Laurent) & 5 & 5 & 5 & 5 & 5 \\
\hline Cantemerle (Macau) & 5 & 5 & 3 & 3 & 5 \\
\hline Cantenac-Brown (Cantenac-Margaux) & 4 & 3 & 4 & 3 & 3 \\
\hline Clerc-Milon (Pauillac) & 2 & 5 & 5 & 4 & 3 \\
\hline Cos-d'Estournel (Saint-Estephe) & 2 & 2 & 2 & 2 & 2 \\
\hline Cos-Labory (Saint-Estephe) & 5 & 5 & 5 & 5 & 5 \\
\hline Croizet-Bages (Pauillac) & 5 & 5 & 5 & 5 & 5 \\
\hline d'Armailhac (Pauillac) & 3 & 5 & 5 & 5 & 5 \\
\hline Dauzac, Labarde (Margaux) & 5 & 5 & 5 & 5 & 3 \\
\hline Desmirail (Margaux) & 5 & 3 & 3 & 3 & 5 \\
\hline d'Issan (Cantenac-Margaux) & 5 & 3 & 3 & 3 & 3 \\
\hline du Tertre, Arsac (Margaux) & 5 & 5 & 4 & 5 & 5 \\
\hline Ducru-Beaucaillou (Saint-Julien) & 2 & 2 & 2 & 2 & 2 \\
\hline Duhart-Milon-Rothschild (Pauillac) & 3 & 4 & 4 & 4 & 3 \\
\hline Durfort-Viviens (Margaux) & 5 & 2 & 4 & 4 & 5 \\
\hline Ferriere (Margaux) & 4 & 3 & 3 & 3 & 5 \\
\hline Giscours (Labarde-Margaux) & 3 & 3 & 2 & 2 & 3 \\
\hline Grand-Puy-Ducasse (Pauillac) & 4 & 5 & 5 & 5 & 5 \\
\hline Grand-Puy-Lacoste (Pauillac) & 2 & 5 & 2 & 2 & 2 \\
\hline Gruaud-Larose (Saint-Julien) & 2 & 2 & 2 & 2 & 3 \\
\hline Haut-Bages-Liberal (Pauillac) & 5 & 5 & 5 & 4 & 4 \\
\hline Haut-Batailley (Pauillac) & 4 & 5 & 3 & 3 & 5 \\
\hline Haut-Brion (Pessac) & 1 & 1 & 1 & 1 & 1 \\
\hline Kirwan (Cantenac-Margaux) & 4 & 3 & 5 & 5 & 3 \\
\hline La Lagune (Ludon) & 3 & 3 & 2 & 2 & 3 \\
\hline La Tour-Carnet (Saint-Laurent) & 5 & 4 & 5 & 4 & 5 \\
\hline Lafite-Rothschild (Pauillac) & 1 & 1 & 1 & 1 & 1 \\
\hline Lafon-Rochet (Saint-Estephe) & 3 & 4 & 5 & 5 & 5 \\
\hline Lagrange (Saint-Julien) & 3 & 3 & 5 & 4 & 4 \\
\hline Langoa-Barton (Saint-Julien) & 3 & 3 & 3 & 3 & 3 \\
\hline Lascombes (Margaux) & 4 & 2 & 3 & 3 & 3 \\
\hline Latour (Pauillac) & 1 & 1 & 1 & 1 & 1 \\
\hline Léoville-Barton (Saint-Julien) & 2 & 2 & 2 & 2 & 2 \\
\hline Léoville-Las-Cases (Saint-Julien) & 1 & 2 & 2 & 2 & 2 \\
\hline Léoville-Poyferre (Saint-Julien) & 3 & 2 & 3 & 3 & 2 \\
\hline Lynch-Bages (Pauillac) & 2 & 5 & 2 & 2 & 2 \\
\hline Lynch-Moussas (Pauillac) & 5 & 5 & 5 & 5 & 5 \\
\hline Malescot-Saint-Exupery (Margaux) & 3 & 3 & 4 & 5 & 2 \\
\hline Margaux (Margaux) & 1 & 1 & 1 & 1 & 1 \\
\hline Marquis d'Alesme-Becker (Margaux) & 5 & 3 & 4 & 5 & 5 \\
\hline Marquis-de-Terme (Margaux) & 5 & 4 & 5 & 5 & 5 \\
\hline Montrose (Saint-Estephe) & 2 & 2 & 2 & 2 & 2 \\
\hline Mouton-Rothschild (Pauillac) & 2 & 1 & 1 & 1 & 1 \\
\hline
\end{tabular}




\begin{tabular}{lrrrrr} 
Palmer (Cantenac-Margaux) & 2 & 3 & 2 & 2 & 2 \\
Pédesclaux (Pauillac) & 5 & 5 & 5 & 5 & 4 \\
Pichon-Lalande (Pauillac) & 2 & 2 & 2 & 2 & 2 \\
Pichon-Longueville Baron (Pauillac) & 2 & 2 & 3 & 3 & 2 \\
Pontet-Canet (Pauillac) & 2 & 5 & 5 & 5 & 2 \\
Pouget (Cantenac-Margaux) & 4 & 4 & 5 & 4 & 4 \\
Prieuré-Lichine (Cantenac-Margaux) & 3 & 4 & 4 & 4 & 4 \\
Rauzan-Gassies (Margaux) & 5 & 2 & 4 & 5 & 4 \\
Rauzan-Segla (Margaux) & 4 & 2 & 3 & 3 & 2 \\
Saint-Pierre (Saint-Julien) & 2 & 4 & 3 & 3 & 4 \\
Talbot (Saint-Julien) & 3 & 4 & 3 & 2 & 4 \\
Total Absolute Deviation from 2010S & N/A & 54 & 42 & 38 & 34 \\
\hline
\end{tabular}


Table 13. Patterns Observed in the Ratings of Wines Rated More Than Once

\begin{tabular}{|c|c|c|c|c|c|c|c|}
\hline \multirow[b]{2}{*}{ \#Ratings } & \multicolumn{6}{|c|}{ Pattern } & \multirow[b]{2}{*}{ Total } \\
\hline & Flat & Increase & Decrease & Up-Down & Down-Up & Other & \\
\hline 2 & 178 & 278 & 274 & & & & 730 \\
\hline 3 & 49 & 134 & 207 & 121 & 117 & & 628 \\
\hline 4 & 3 & 15 & 24 & 24 & 18 & 11 & 95 \\
\hline 5 & 3 & 1 & 5 & 8 & 5 & 13 & 35 \\
\hline 6 & & 2 & 1 & 1 & 3 & 12 & 19 \\
\hline 7 & & & & & & 6 & 6 \\
\hline 8 & & & 1 & & 1 & 1 & 3 \\
\hline 9 & & & & 1 & & & 1 \\
\hline 10 & & & & & & 1 & 1 \\
\hline 11 & & & & & & & 0 \\
\hline 12 & & & & & & 2 & 2 \\
\hline
\end{tabular}




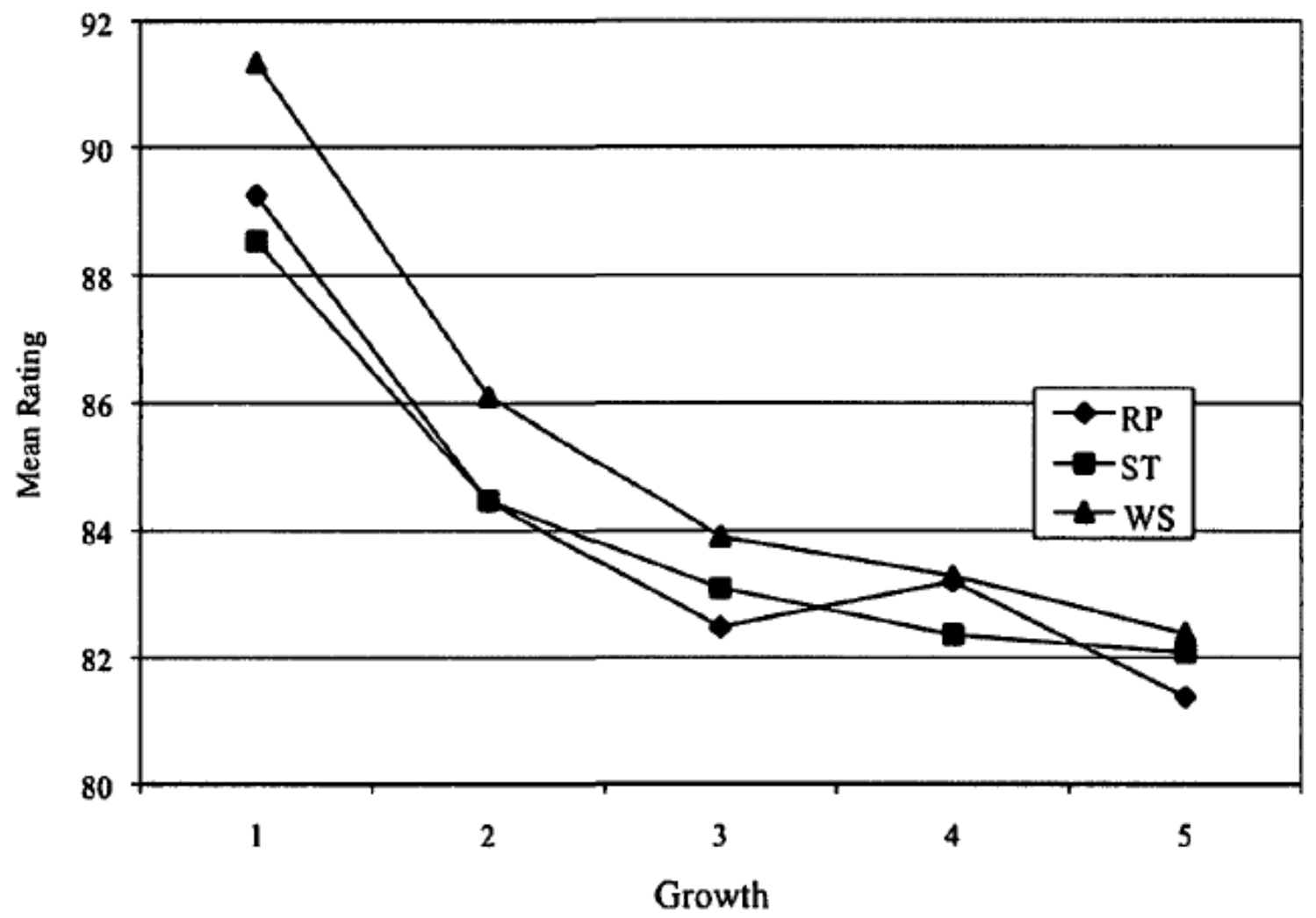

Figure 1. Average Scores, by Rater and Growth (adjusted by rated vintage and chateau) 


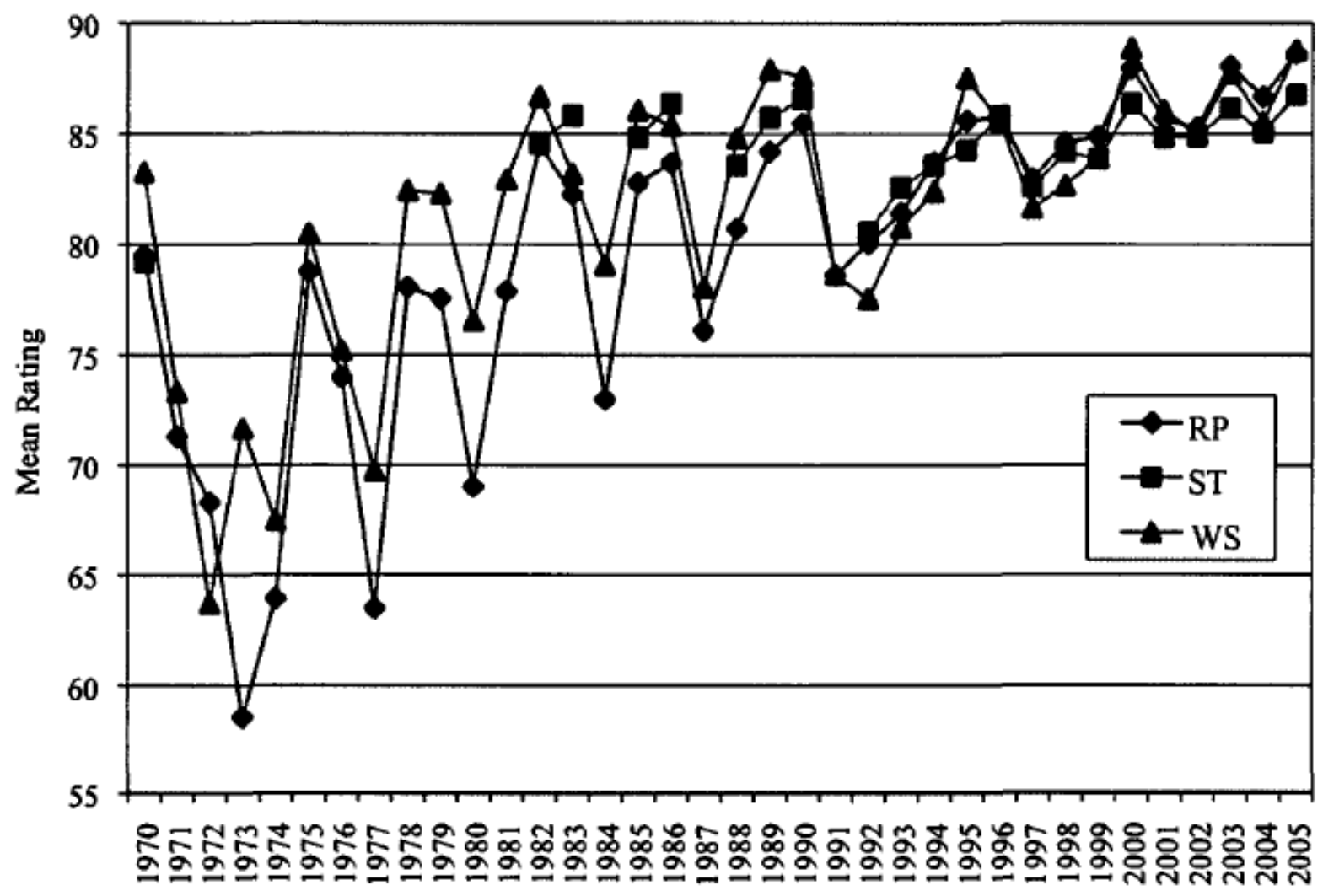

Figure 2. Average Ratings, by Rater and Vintage (adjusted by rated château) 


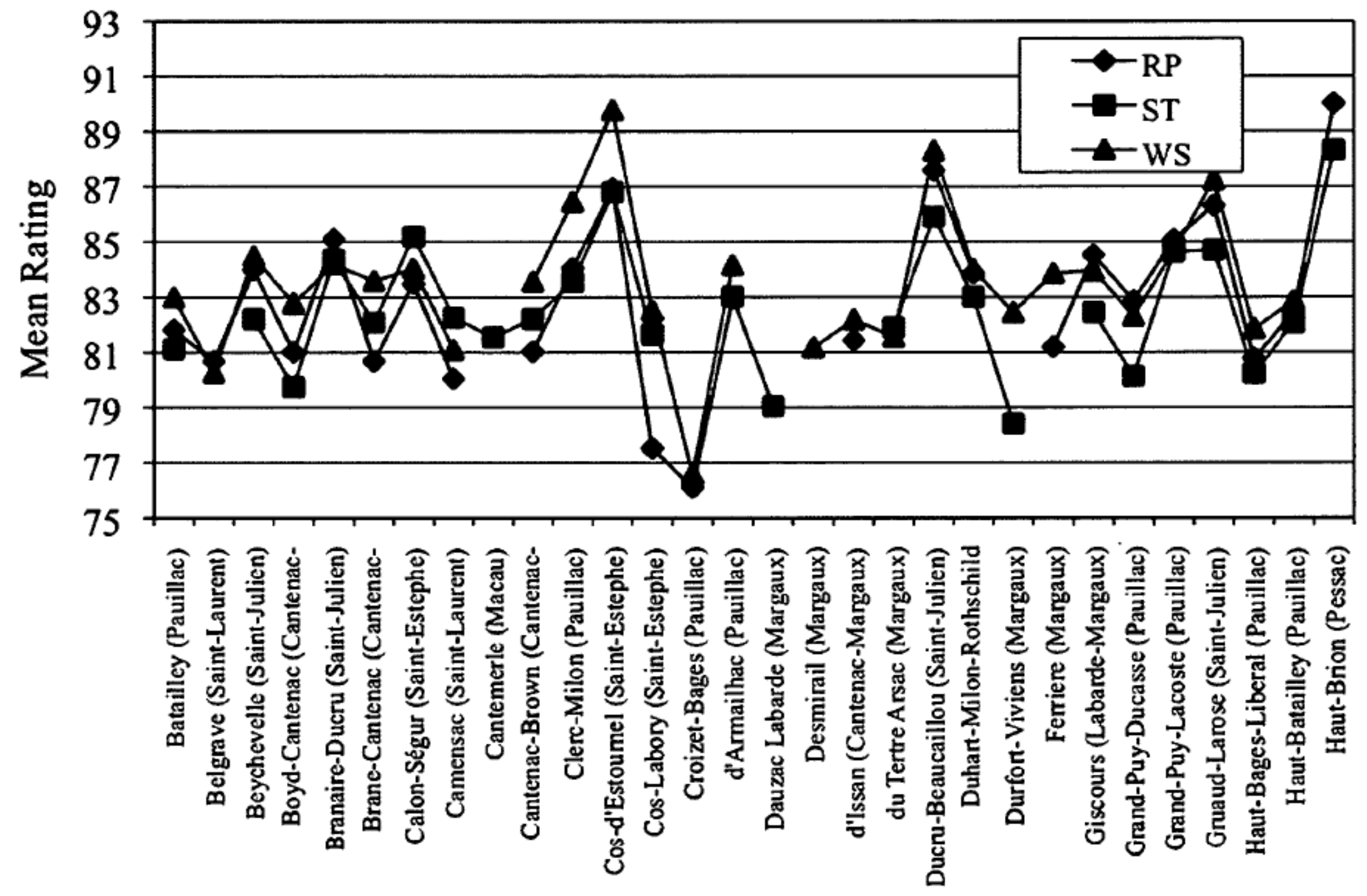

Figure 3A. Average Rating by Rater and Château (adjusted by rated vintage) 


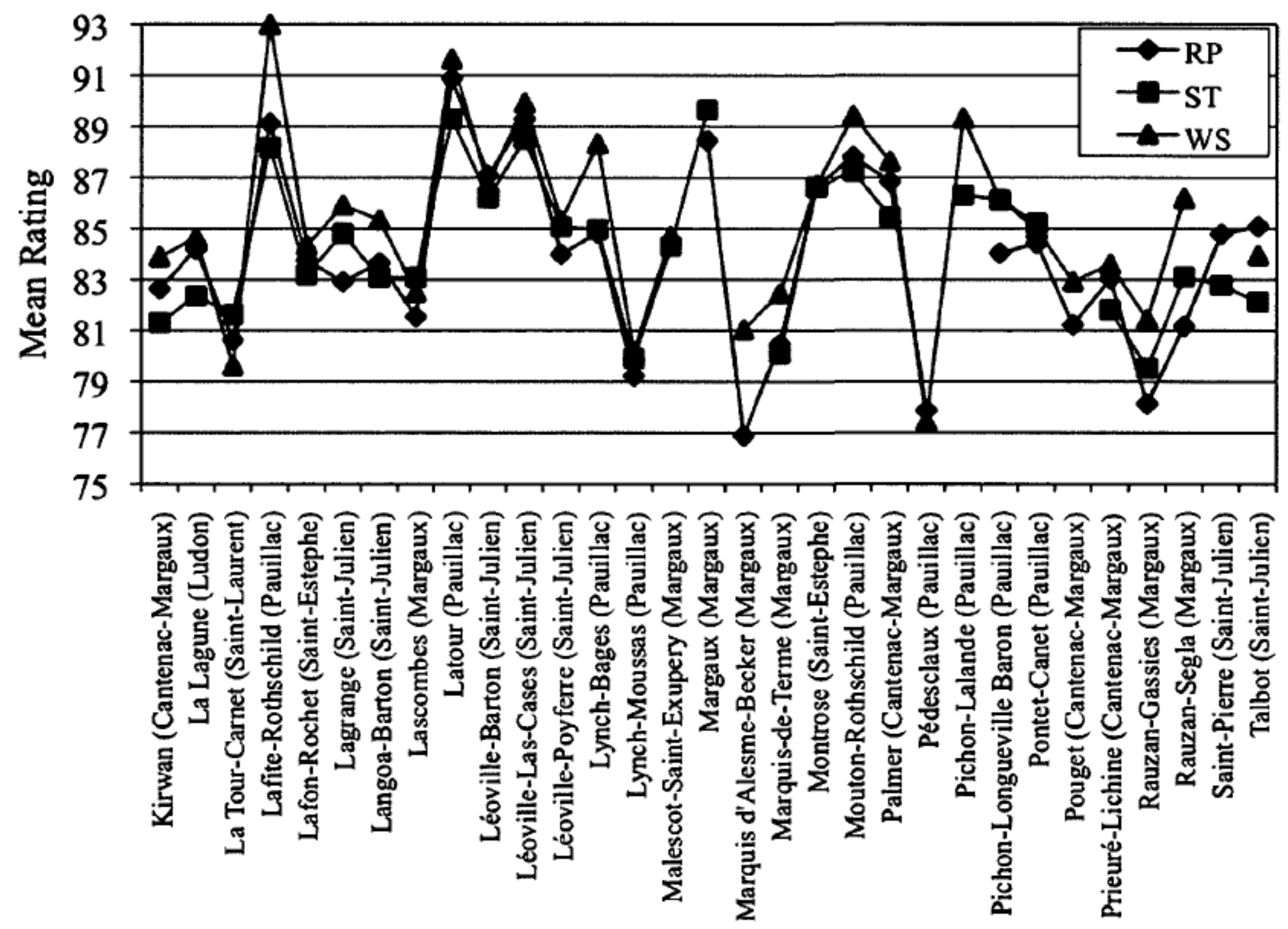

Figure 3B. Average Rating by Rater and Château (adjusted by rated vintage) 